\title{
Intellectual Property Information Service in Colleges and Universities Under the Background of Innovation Driven
}

\author{
Li Yuan ${ }^{1,2}$ \\ ${ }^{1}$ School of Management, Henan Institute of Technology, Xinxiang, Henan, China \\ ${ }^{2}$ School of Management, UCSI University, Kuala Lumpur Campus, Malaysia
}

\begin{abstract}
:
This paper studies the intellectual property information service in Colleges and Universities under the background of innovation driven. Firstly, this paper expounds the concept and characteristics of intellectual property management in knowledge intensive manufacturing industry. On this basis, this paper compares and analyzes the current situation of intellectual property in knowledge intensive manufacturing industry at home and abroad from the aspects of intellectual property development, operation, protection and coordination, and finds out the achievements and shortcomings of intellectual property management in knowledge intensive manufacturing industry in China. This paper analyzes the hypercycle model of knowledge transfer and the collaborative evolution mechanism of knowledge transfer in knowledge intensive manufacturing industry by using the relevant theories of linkage and hypercycle. On this basis, the linkage relationship between knowledge transfer and intellectual property management in knowledge intensive manufacturing industry is analyzed. Based on the specific domestic intellectual property environment, this paper constructs the intellectual property management system of China's knowledge intensive manufacturing industry from three dimensions: intellectual property development, intellectual property protection and intellectual property operation. .
\end{abstract}

Keywords: .Innovation Driven, Intellectual Property, Information Service, Intellectual Property Operation.

\section{INTRODUCTION}

Manufacturing industry is the pillar industry of China's national economy, leading the development of China's economy [1-2]. As the most important part of manufacturing industry, knowledge intensive manufacturing industry has become an important support for China's 
Article History: Received: 28 October 2021 Revised: 05 December 2021 Accepted: 10 January 2022 Publication: 28 February 2022

economic and social development. Because intellectual property has the characteristics of monopoly, transferability and high input-output ratio, the development speed of knowledge intensive manufacturing industry has the potential to catch up with and surpass the traditional manufacturing industry in a short time [3-4]. With the rapid development of knowledge intensive manufacturing industry in China, many problems need to be faced and solved. For example, China's knowledge intensive manufacturing industry has unreasonable intellectual property management institutions, imperfect policies and systems, lack of legal protection, shortage of intellectual property professionals, imperfect intellectual property information system and so on [5].

If these practical problems can not be solved, it will directly affect the future development speed of China's knowledge intensive manufacturing industry and put China's knowledge intensive manufacturing industry in an unfavorable international market competition environment. Therefore, in view of China's actual situation, it is necessary to carry out the research on intellectual property management of China's knowledge intensive manufacturing industry, so as to ensure the smooth development of technology R \& D behavior, production operation behavior and market operation behavior of China's knowledge intensive manufacturing industry from multiple angles and links [5-6]. Create a relatively fair international competitive environment and improve the overall level of intellectual property management in China's knowledge intensive manufacturing industry.

\section{LINKAGE ANALYSIS OF KNOWLEDGE TRANSFER AND INTELLECTUAL PROPERTY MANAGEMENT IN KNOWLEDGE INTENSIVE MANUFACTURING INDUSTRY}

Knowledge transfer in knowledge intensive manufacturing industry has the following characteristics:

(1) The circular interaction of knowledge transfer. Knowledge transfer in knowledge intensive manufacturing industry is a two-way process, which requires two-way exchange of knowledge between core enterprises and peripheral enterprises [7]. The acquisition of knowledge does not mean the end of the process of knowledge transfer. After acquiring knowledge, enterprises also need to analyze the results of knowledge transfer, further absorb and integrate the acquired knowledge, and the acceptance effect of knowledge.

(2) Timeliness of knowledge transfer. Knowledge intensive manufacturing industry is faster than ordinary manufacturing industry in terms of knowledge aging and renewal speed, so the knowledge creator in knowledge intensive manufacturing industry needs to do everything possible to overcome the constraints of knowledge transfer. Accelerate the transfer of knowledge and invest new knowledge into manufacturing production activities in the shortest time and at the lowest cost, so as to create greater value [8]. 
Article History: Received: 28 October 2021 Revised: 05 December 2021 Accepted: 10 January 2022 Publication: 28 February 2022

(3) The radiation diffusion of knowledge transfer. For countries, knowledge transfer in knowledge intensive manufacturing industry improves the overall effect of manufacturing innovation, and will eventually lead to the common development of society and national economy. Therefore, as a knowledge intensive manufacturing industry, each unit will follow the overall goal of knowledge transfer. While knowledge intensive manufacturing enterprises transfer knowledge to each other, they will have a strong radiation effect on other enterprise subjects and promote the innovation and development of enterprise subjects.

Knowledge transfer in knowledge intensive manufacturing industry is a cross field knowledge transfer circulating among different fields. The effect of knowledge transfer will determine the effect of improving the competitiveness of knowledge intensive manufacturing industry. Knowledge intensive manufacturing industry is a large hypercycle system, in which every core enterprise and peripheral enterprise are basic organizations. These organizations have the ability to transform knowledge into economic and social benefits. For the knowledge flow of knowledge intensive manufacturing industry, first of all, knowledge flow needs a certain infrastructure, technical foundation and knowledge base, and follows certain national or regional formal rules and practices. At the same time, a certain number of people need to encourage the flow of knowledge. At the same time, knowledge flow needs certain capital support. In addition to the knowledge owner's own capital, these capital also comes from public financial expenditure and risk investment. As the main components of knowledge in knowledge intensive manufacturing industry, stock knowledge, external knowledge and new knowledge transfer each other within and among organizations, and are constantly mutated and inherited. Form a knowledge proliferation flow network, maintain the hypercycle of the life body of knowledge intensive manufacturing industry, and improve the innovation efficiency of knowledge intensive manufacturing industry. The knowledge transfer hypercycle model of knowledge intensive manufacturing industry includes knowledge transfer reaction cycle, knowledge transfer catalytic cycle and knowledge transfer hypercycle.

The existence of knowledge transfer hypercycle in knowledge intensive manufacturing industry overcomes the disadvantage of uneven distribution of scientific and technological resources in manufacturing enterprises, makes up for the lack of innovation resources, makes the knowledge of knowledge intensive manufacturing industry overflow, spread, share and reproduce continuously, reduces the cost of knowledge transfer and enhances the innovation ability of knowledge intensive manufacturing industry. At the same time, due to the different time domain, region or technical field, the knowledge carrier and knowledge innovation mode will also be different, which makes the knowledge transfer of knowledge intensive manufacturing industry in a variety of contradictions under different external effects. These contradictions interact to form a relatively stable knowledge transfer mode. A specific knowledge transfer mode will have a specific knowledge absorption mode and knowledge mutation critical point. In various modes of knowledge transfer in knowledge intensive 
Article History: Received: 28 October 2021 Revised: 05 December 2021 Accepted: 10 January 2022 Publication: 28 February 2022

manufacturing industry, without considering the influence of external factors, synergy and evolution mechanism will always make knowledge transfer reach an orderly and stable state and make the hypercycle run normally. Therefore, the co evolution mechanism of knowledge transfer in knowledge intensive manufacturing industry can be divided into coupling enhancement mechanism, self-organization stability mechanism, mutation dynamic mechanism and competition guarantee mechanism.

\section{CONSTRUCTION OF INTELLECTUAL PROPERTY MANAGEMENT SYSTEM IN KNOWLEDGE INTENSIVE MANUFACTURING INDUSTRY}

Intellectual property management system of knowledge intensive manufacturing industry refers to the knowledge intensive manufacturing industry to improve its independent innovation ability and market competitiveness. To achieve the organizational objectives, the intellectual property development process, protection process and operation process are managed in an allround way. The intellectual property management system is an evolving coupling whole with certain power support, which is organically composed of subsystems such as intellectual property development management, intellectual property protection management and intellectual property operation management.

On the basis of clear structure, clear responsibilities and perfect functions, the intellectual property management system of knowledge intensive manufacturing industry needs to achieve the following direct objectives:

(1) Provide efficient and convenient auxiliary tools for intellectual property development, so that intellectual property development decision-makers can obtain relatively accurate and detailed relevant data of pre developed intellectual property in the shortest time, quickly locate and select the best development mode;

(2) By standardizing the intellectual property value evaluation strategy, determine different types of intellectual property transaction strategies, and form a perfect intellectual property transaction market;

(3) Through the analysis of intellectual property protection mode, this paper analyzes and summarizes the whole process of intellectual property application and confirmation, intellectual property risk prevention and intellectual property dispute handling, so as to further improve and optimize the intellectual property protection system.

Intellectual property is an important intangible asset of knowledge intensive manufacturing industry. In intellectual property transactions and infringement claims, the value of intellectual property needs to be evaluated, and the value of intellectual property is generally reflected by the market exchange price. When evaluating the value of intellectual property, it is often necessary to ensure that the evaluation method matches the type of evaluation value, the evaluation method matches the state of the evaluation object, and the evaluation method 
Article History: Received: 28 October 2021 Revised: 05 December 2021 Accepted: 10 January 2022 Publication: 28 February 2022

matches the evaluation purpose. The specific evaluation methods of intellectual property value of knowledge intensive manufacturing industry are shown in Table 1.

TABLE I. Evaluation method of intellectual property rights of knowledge intensive manufacturing enterprises

\begin{tabular}{|c|c|c|c|}
\hline METHOD & $\begin{array}{c}\text { APPLICATION } \\
\text { HYPOTHESIS }\end{array}$ & ADAPTIVE SUBJECT & $\begin{array}{c}\text { EVALUATION } \\
\text { KEY }\end{array}$ \\
\hline $\begin{array}{c}\text { Replacement } \\
\text { cost method }\end{array}$ & $\begin{array}{c}\text { Every dollar spent in the } \\
\text { research process can } \\
\text { achieve the same effect }\end{array}$ & $\begin{array}{c}\text { Enterprises with } \\
\text { independent development } \\
\text { and reverse engineering } \\
\text { experience }\end{array}$ & $\begin{array}{c}\text { Forecast the cost of } \\
\text { independent } \\
\text { development and } \\
\text { reverse engineering }\end{array}$ \\
\hline $\begin{array}{c}\text { Discounted } \\
\text { cash flow } \\
\text { method }\end{array}$ & $\begin{array}{c}\text { Intellectual property can } \\
\text { generate a series of cash } \\
\text { flows }\end{array}$ & $\begin{array}{c}\text { The enterprise does not } \\
\text { intend to implement this } \\
\text { intellectual property right, } \\
\text { nor does it intend to restrict } \\
\text { competitors from using this } \\
\text { intellectual property right }\end{array}$ & $\begin{array}{c}\text { The choice of } \\
\text { discount rate predicts } \\
\text { the time of cash flow } \\
\text { and cash income }\end{array}$ \\
$\begin{array}{c}\text { Market value } \\
\text { method }\end{array}$ & $\begin{array}{c}\text { Intellectual property is in } \\
\text { an effective market }\end{array}$ & $\begin{array}{c}\text { Enterprises that take the } \\
\text { current price in the } \\
\text { intellectual property market } \\
\text { as the price standard }\end{array}$ & $\begin{array}{c}\text { Refer to the market } \\
\text { price of resources } \\
\text { that are the same or } \\
\text { similar to the } \\
\text { appraised object }\end{array}$ \\
\hline $\begin{array}{c}\text { Value } \\
\text { increment } \\
\text { method }\end{array}$ & $\begin{array}{c}\text { Use the same technology } \\
\text { as competitors }\end{array}$ & $\begin{array}{c}\text { In the early stage, } \\
\text { enterprises monopolized the } \\
\text { use of intellectual property } \\
\text { rights, and in the later stage, } \\
\text { competitors using the same } \\
\text { intellectual property rights } \\
\text { appeared in the same } \\
\text { industry }\end{array}$ & $\begin{array}{c}\text { Predict the annual } \\
\text { profit of intellectual } \\
\text { property operation } \\
\text { under monopoly and } \\
\text { competition } \\
\text { conditions } \\
\text { respectively }\end{array}$ \\
\hline $\begin{array}{c}\text { Real option } \\
\text { method }\end{array}$ & $\begin{array}{c}\text { The cash flow increased } \\
\text { by enterprise in each } \\
\text { period is uncertain }\end{array}$ & $\begin{array}{c}\text { Enterprises that can } \\
\text { implement and give up } \\
\text { intellectual property rights }\end{array}$ & $\begin{array}{c}\text { Measure the value of } \\
\text { the option set formed } \\
\text { by the } \\
\text { implementation of } \\
\text { intellectual property } \\
\text { rights }\end{array}$ \\
\hline
\end{tabular}

Intellectual property is an intangible asset of knowledge intensive manufacturing industry. Only when this intangible asset is effectively allocated can it create competitive advantage and development power for knowledge intensive manufacturing industry. Knowledge intensive 
Article History: Received: 28 October 2021 Revised: 05 December 2021 Accepted: 10 January 2022 Publication: 28 February 2022

manufacturing enterprises can effectively enhance their core competitiveness only by giving full play to the diffusion effect of intellectual property in the intellectual property trading market, optimizing the rational distribution of intellectual property resources and transforming intellectual resources into market competitive advantages. Therefore, on the basis of determining and evaluating the value of intellectual property, knowledge intensive manufacturing industry should actively take measures to give full play to the value brought by the marketization, industrialization and capitalization of intellectual property, so as to turn the intellectual achievements created by enterprises into the maximum economic and development benefits.

\section{DYNAMIC MECHANISM OF INTELLECTUAL PROPERTY MANAGEMENT SYSTEM IN KNOWLEDGE INTENSIVE MANUFACTURING INDUSTRY}

For intellectual property management in knowledge-intensive manufacturing industry, the government is leading the formulation of policies and laws, and bears the greatest responsibility. Although people's awareness of intellectual property management can be used as a reference for policy decision-making through research, demonstration and opinion uploading. However, the realization of the final policy is accomplished by relevant national systems, strategies or laws and regulations, which is why these systems, strategies and laws and regulations represent the will of the country. The government's behavior of intellectual property management supports the operation of intellectual property management system in knowledge-intensive manufacturing industry. After determining the strategic objectives and carefully analyzing the development status and historical experience and lessons of intellectual property in knowledgeintensive manufacturing industry, the government's behavior of intellectual property management in knowledge-intensive manufacturing industry at least includes construction behavior, service behavior, guarantee behavior and coordination behavior (see Figure 1). 
Article History: Received: 28 October 2021 Revised: 05 December 2021 Accepted: 10 January 2022 Publication: 28

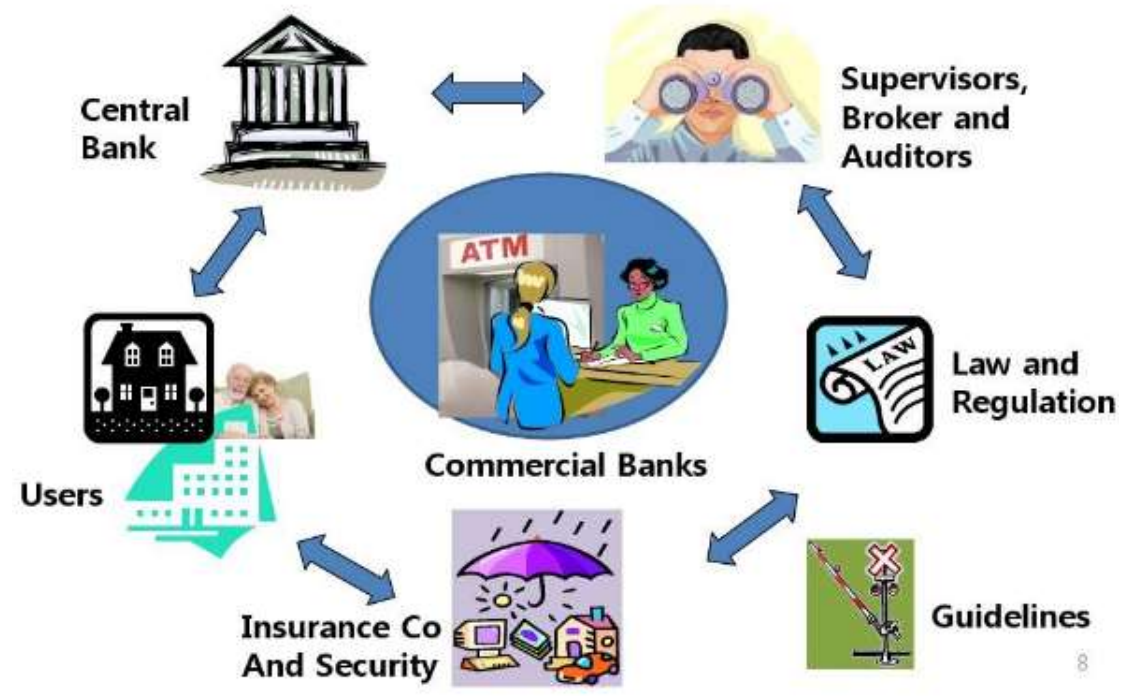

Fig 1: Government's Behavior in Intellectual Property Management of Knowledge-intensive Manufacturing Industry

The economic benefits of knowledge intensive manufacturing enterprises are realized through the commercialization of innovative knowledge achievements. The commercialization of knowledge achievements not only improves the expenditure for independent innovation of enterprises, but also provides market information feedback for independent innovation of enterprises, so as to realize the virtuous circle of independent innovation of knowledge intensive manufacturing enterprises (see Figure 2). The relatively complete intellectual property management activities of knowledge intensive manufacturing industry should include the whole process from innovative knowledge conception to knowledge commercialization. Knowledge intensive manufacturing enterprises should carry out intellectual property retrieval in the pre innovation stage, implement technical supervision in the innovation stage, and explore the transformation mode in the commercialization stage. 
Article History: Received: 28 October 2021 Revised: 05 December 2021 Accepted: 10 January 2022 Publication: 28 February 2022

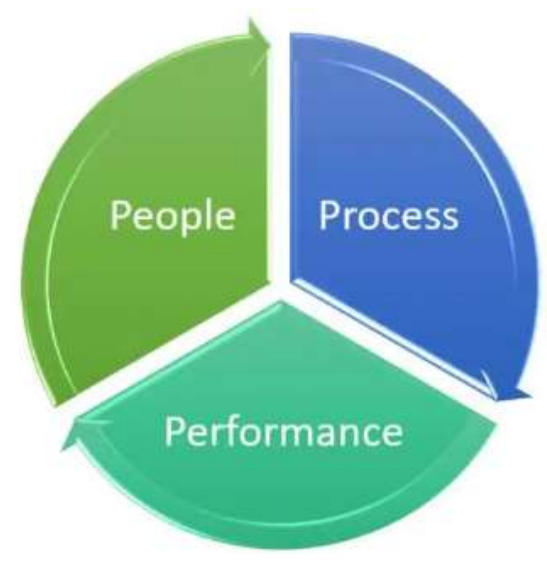

Fig 2: Intellectual property management promotes the virtuous circle of independent innovation in knowledge intensive manufacturing industry

In the process of developing new knowledge achievements in knowledge intensive manufacturing enterprises, by querying the completed knowledge achievements such as relevant intellectual property rights and technical secrets in internal and external knowledge databases, it can reduce repeated $\mathrm{R} \& \mathrm{D}$ and improve $\mathrm{R} \& \mathrm{D}$ efficiency; The sharing and exchange of intellectual property information and the paid transfer of technology are conducive to the dissemination of innovative knowledge achievements, the optimal allocation of technical resources within, among and with other types of enterprises in knowledge intensive manufacturing enterprises, and the formation of independent intellectual property rights in key fields.

\section{CONCLUSION}

In the era of knowledge economy, the benefits of knowledge intensive manufacturing industry to economy and society are becoming increasingly prominent. In recent years, China has continuously strengthened its support for knowledge intensive manufacturing industry, and paid more and more attention to knowledge intensive manufacturing industry. Simultaneous interpreting is not only the ultimate product and main business object of knowledge intensive manufacturing industry, but also an important distinction between knowledge intensive manufacturing and traditional manufacturing. Therefore, the knowledge intensive manufacturing industry is required to pay attention to the process of intellectual property development, protection and operation, and strive for systematic and scientific intellectual property management. This paper analyzes and studies the intellectual property management of China's knowledge intensive manufacturing industry by using the relevant theories such as intellectual property management theory, system theory and technological innovation theory. 


\section{REFERENCES}

[1] Lyster, \& Norman, C., The use of the music operating system to supplement the teaching of cobol. ACM Sigcse Bulletin, vol.18, no. 4, pp. 46-49, 1986.

[2] Oliveira, \& A. Music teaching as culture: introducing the pontes approach. International Journal of Music Education, vol.23, no. 3, pp. 205-216, 2005.

[3] Ilhan Özgül. An analysis of the elementary school music teaching course in turkey. International Journal of Music Education, vol.27, no. 2, pp. 116-127, 2009.

[4] Boulet, \& Marie-Michele. Designing and developing an intelligent advisor system for transfer tasks in music. Computers \& Education, vol.19, no. 4, pp. 341-357, 1992.

[5] Hodge, G. M., Jupp, J. J., \& Taylor, A. J. . Work stress, distress and burnout in music and mathematics teachers. British Journal of Educational Psychology, vol.64, no. 1, pp. 65-76, 2011.

[6] Yang, L., Ketner, K., Luker, S., \& Patterson, M. . A complete system for publishing music-related etds. Library Hi Tech, vol.34, no. 1, pp. 151-163, 2016.

[7] Hwong, N. C., Caswell, A., Johnson, D. W., \& Johnson, R. T. . Effects of cooperative and individualistic learning on prospective elementary teachers' music achievement and attitudes. Journal of Social Psychology, vol.133, no. 1, pp. 53, 1993.

[8] Maganioti, A.E., Chrissanthi, H.D. "Cointegration of Event-Related Potential (ERP) Signals in Experiments with Different Electromagnetic Field (EMF) Conditions". Health, vol.12, no.2, pp.400406, 2016. 